\title{
Die teksfunksie en boodskap van Jesaja 49:1-6
}

\author{
A A da Silva (postuum) 1 \\ soos verwerk deur A P B Breytenbach \\ Universiteit van Pretoria
}

\begin{abstract}
The textual function and message of Isaiah 49:1-6

The purpose of this article is to arrive at legitimate deductions about the textual

function and the theological message of Isaiah 49:1-6. This goal is pursued by

means of a method consisting of a synchronic analysis, a diachronic analysis, and a reception-critical analysis.
\end{abstract}

\section{DOEL EN METODE}

Jesaja 49:1-6 is 'n teks waarin die eksegeet met verskeie vraagstukke gekonfronteer word. As een van die sogenaamde "Knegliedere" in Deuterojesaja stel dit die eksegeet veral voor drie uitdagings: wat is Jesaja 49:1-6 se verhouding tot die ander knegliedere, watter funksie vervul die liedere in die opbou van die boek en wat kan uit die teks oor die identiteit van die kneg afgelei word (vgl Beuken 1978:23-24)? Die doel van hierdie artikel is om wetenskaplik verantwoorde afleidings te maak oor die teksfunksie en die teologiese boodskap van Jesaja 49:1-6. ${ }^{2}$ Die metode wat vir dié doel gebruik word, is 'n

\footnotetext{
1 Die artikel is grondig hersien deur proff G T M Prinsloo en P J Botha van die Departement Antieke Tale aan die Universiteit van Pretoria. Die artikel het aanvanklik bestaan uit klasaantekeninge van prof A A da Silva vir derdejaarstudente. Die klasse is aangebied gedurende 1998, sy laaste jaar van aktiewe akademiese werk voordat ernstige siekte hom tot vroegtydige aftrede gedwing het. Dit is vir ons 'n voorreg om die laaste akademiese arbeid van ons afgestorwe kollega in hierdie formaat die lig te laat sien.

2 Jesaja 49:1-6 is die tweede van die sogenaamde "Knegliedere" in Deuterojesaja. Die bedoeling van die artikel is nie om in detail aandag te skenk aan die ingewikkelde problematiek rondom die plek van die "Knegliedere" in Deuterojesaja (vgl Spykerboer 1976:162-166) of die debat rondom die identiteit van die "Kneg van die Here" in die boek nie (vgl North 1948 vir 'n uitgebreide oorsig). Die artikel toon wel dat 'n noukeurige lees van die teks op verskillende vlakke die eksegeet voorsien van 'n raamwerk waarbinne verantwoordelike interpretasie geskied. Dit weerhou die eksegeet van subjektiewe besluite wat van buite die teks ingelees word.
} 
eksegese wat uit drie fasette bestaan, naamlik 'n sinchroniese analise, 'n diachroniese analise en 'n resepsie-kritiese analise.

\section{SINCHRONIESE ANALISE}

In hierdie faset word gewerk met die teks soos dit tans daar uitsien, los van enige ekstratekstuele verbande. Die verskillende stappe van hierdie faset is teksafbakening, tekskritiek, morfologiese analise, sintaktiese analise, stigometriese analise en poëtiese analise.

\section{$2.1 \quad$ Teksafbakening}

\subsubsection{Afgrensing van Jesaja 48:22 teenoor 49:1.}

Dit is duidelik dat Jesaja 49:1 die begin van 'n nuwe gedeelte verteenwoordig. Formeel gesproke is die subjek van Jesaja 48:22 'n derde persoon manlik enkelvoud (Jahwe); terwyl dit in Jesaja 49:1 'n tweede persoon manlik meervoud (julle) is. Verder is die werkwoordvorm van Jesaja 48:22 in die perfektum; maar 49:1 begin met 'n imperatief. Op 'n inhoudelike vlak kan gesê word dat dit in Jesaja 48:22 gaan oor Jahwe en in 49:1 beveel die עֶבֶב die eilande en die nasies om te luister. Hier is dus 'n subjekwisseling sowel as 'n tematiese wisseling. Die pronominale suffiks van die eerste persoon enkelvoud is die eerste van veertien soortgelyke suffikse waarmee die עִ קֶבד ידוה in die volgende vyf verse na homself verwys.

\subsubsection{Afgrensing van Jesaja 49:6 teenoor 49:7}

In hierdie artikel word betoog dat die perikoop tot by Jesaja 49:6 strek. Die redes daarvoor is eerstens formeel dat daar in Jesaja 49:6 'n imperfektum voorkom waaraan die waw-konsekutief gevoeg is. In Jesaja 49:7 is die werkwoordvorm daarenteen 'n perfektum sonder die waw-konsekutief. Inhoudelik kan gesê word dat die laaste deel van Jesaja 49:6 handel oor Jahwe se opdrag aan die עֶֶֶ; terwyl Jesaja 49:7 'n inleidingsformule tot 'n nuwe eenheid vorm. In Jesaja 49:6 praat Jahwe twee keer mét sy

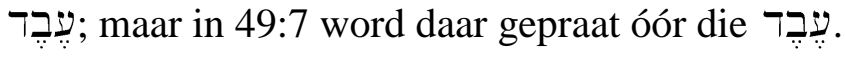


Op grond van bogenoemde kan aanvaar word dat Jesaja 49:1-6 'n afgeronde, selfstandige perikoop is.

\subsection{Tekskritiek}

Slegs twee van die tekskritiese notas in Biblia Hebraica Stuttgartensia verdien besondere aandag. In vers 5a lees die Qumran-teks, 'n paar manuskripte van die Septuaginta, die לא Targoem, die teks van Aquila en die Ethiopiese vertaling לו (vir hom), in plaas van (nie) soos in die Masoretiese teks. Die vraag of 'n wysiging nodig is, sal deur die verdere ontleding bepaal word.

In vers 5b het die 1933 Afrikaanse vertaling die moeilike sinsnede לא יאָָסף weergegee met: "dat (Israel) by Hom versamel mag word". In die Nuwe Afrikaanse Vertaling is die werkwoord geïnterpreteer as 'n vorm van en vertaal met: "sodat (Israel) nie meer verstrooi sal wees nie". Die Siriese en die Arabiese vertalings gebruik in hierdie geval die vorm ' $k n s$, wat die 'Af'el-stamformasie is van kns, 'n sinoniem van אסֵך. Met die oog op 'n sinvoller lesing word daar in die tekskritiese apparaat voorgestel

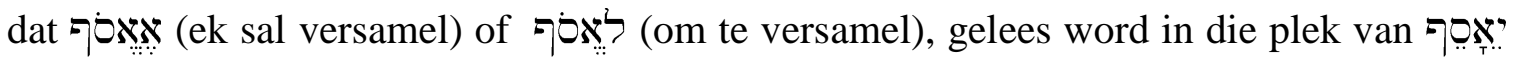
לא. Hierdie voorstel word egter nie deur gesaghebbende, onafhanklike teksgetuies gesteun nie. Daarom sal eers later op grond van literêr-kritiese oorwegings bepaal word of ' $\mathrm{n}$ verandering nodig is. Afgesien van hierdie twee gevalle is daar geen verdere probleme in die teks nie. ${ }^{3}$

\subsection{Morfologiese analise}

'n Morfologiese analise van Jesaja 49:1-6 toon dat die עֶברד in 49:1-6 na vier rolspelers verwys. Daar word drie en twintig keer na Jahwe verwys, en vier en twintig keer na homself. Daarteenoor verwys die skrywer net vier keer na die volk van God (wat hy in vers 5-6 "Israel" en "Jakob" noem). Hy verwys ook vier keer na die nasies buite Israel.

3 Beuken (1978:38) wys daarop dat die verwysing na "Israel" in 49:3 in 'n enkele Hebreeuse manuskrip ontbreek. Dit het in die debat oor die identiteit van die kneg in Deutero-Jesaja 'n strydpunt geword wat buite alle verhouding met die gewig van die teksgetuie is. Aanhangers van ' $n$ individualistiese interpretasie laat "Israel" hier weg (vgl. Die bespreking in Koole 1998:4). Aanhangers van 'n kollektiewe interpretasie behou dit. Daar is egter geen rede om "Israel" hier weg te laat nie. Ten minste wat Jesaja 49:1-6 betref kan daar geen twyfel wees dat die kneg op gewalifiseerde wyse met die volk Israel (in die sin dat dit die Israel van die ballingskap is) gelykgestel word nie. 
Hy spreek hulle in vers 1 aan as "eilande" en "nasies wat ver is" en in vers 6 as "nasies" en "eindes van die aarde". Die verwysings na die vreemde volke aan die begin en einde van die perikoop suggereer 'n inclusio.

Die morfologiese analise bevestig dat die עֶבֶד ידוה Jahwe se optredes voorop wil stel. Wat Jahwe deur sy עֶֶר doen, raak Israel en die ander nasies direk.

Die morfologiese analise toon verder 'n anomalie: In 49:3 sê Jahwe vir sy עֶֶר: “jy is Israel”; maar in 49:5-6 kry dieselfde שֵֶׁ die opdrag om Israel na God toe terug te bring. Die probleem wat hierdie anomalie oplewer, kan nie op grond van die morfologiese analise opgelos word nie. Dit sal moontlik uit die verdere eksegetiese stappe blyk wie nou eintlik die עְבְד יהוה is.

\subsection{Sintaktiese analise}

Uit 'n sintaktiese analise van Jesaja 49:1-6 blyk die volgende: Die perikoop bestaan uit twaalf enkelvoudige sinne en vier saamgestelde sinne waarvan die hoofwerkwoorde telkens ' $\mathrm{n}$ vorm van die werkwoord is. ${ }^{4}$ Die eerste sinne van die perikoop is twee bevelsinne: "Luister ...” en "Gee aandag ...." (1ab) Hierdie bevele funksioneer as 'n inleiding tot die hele gedeelte. Daar word in agt eenhede uiteengesit waarna die nasies moet luister. Met twee stelsinne sê die spreker dat Jahwe hom reeds voor sy geboorte tot diens geroep het (1cd). Met vier stelsinne sê hy hoe Jahwe hom vir sy taak toegerus het (2a-d). Met die eerste van die vier saamgestelde stelsinne (3ab) sê hy dat Jahwe Israel wou gebruik om sy mag bekend te maak. Met die tweede saamgestelde stelsin (4ab) sê hy hoe teleurgesteld hy is oor die volk se reaksie. Met twee parenteses $(4 \mathrm{~cd})$ sê hy dat God self vir hom 'n beloning op sy arbeid sal gee. Met die derde saamgestelde stelsin (5a-d) sê hy wat sy primêre opdrag was: Hy moes naamlik vir Jakob en Israel weer na God teruglei. Met twee parenteses (5ef) sê hy hoe Jahwe hom vir hierdie taak toegerus het. Met die laaste van die saamgestelde stelsinne (6a-e) sê hy hoe Jahwe sy roeping vergroot het: Hy moet nou ook aan die nasies buite Israel verlossing verkondig.

Hierdie analise dwing die eksegeet om noukeurig kennis te neem van die inhoud van elke sin en van die verbande wat tussen daardie sinne bestaan.

$4 \mathrm{Vgl}$ die stigometriese analise hieronder vir die indeling van die Masoretiese teks in versreëls en versvoete. 


\subsection{Stigometriese analise}

Omdat Jesaja 49:1-6 poësie is, moet die eenheid ook stilisties geanaliseer word. Die eerste faset hiervan is 'n stigometriese analise wat van links na regs soos volg ingedeel word: Stansa, strofe, versreël, versvoet, metrum, Hebreeuse teks en Bybelversnommers.

\begin{tabular}{|c|c|c|c|c|c|c|}
\hline Stansa & Strofe & Versreël & Versvoet & Metrum & Teks & $\begin{array}{c}\text { Vers- } \\
\text { nommer }\end{array}$ \\
\hline \multirow[t]{2}{*}{ I } & A & 1 & $\mathrm{a}$ & 3 & 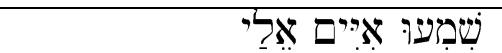 & $1 \mathrm{a}$ \\
\hline & & & $\mathrm{b}$ & 3 & 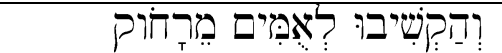 & $\mathrm{b}$ \\
\hline \multirow[t]{12}{*}{ II } & B & 2 & $\mathrm{a}$ & 3 & 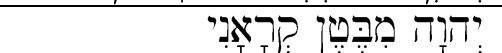 & $\mathrm{c}$ \\
\hline & & & $\mathrm{b}$ & 4 & 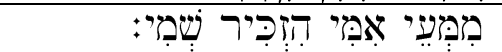 & $\mathrm{d}$ \\
\hline & & 3 & $\mathrm{a}$ & 4 & 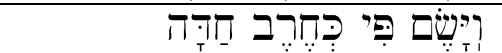 & $2 \mathrm{a}$ \\
\hline & & & $\mathrm{b}$ & 3 & 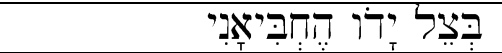 & $\mathrm{b}$ \\
\hline & & 4 & $\mathrm{a}$ & 3 & 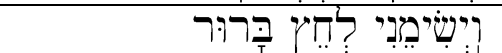 & $\mathrm{c}$ \\
\hline & & & $\mathrm{b}$ & 2 & 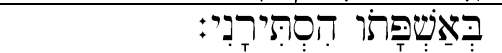 & $\mathrm{d}$ \\
\hline & $\mathrm{C}$ & 5 & $\mathrm{a}$ & 3 & 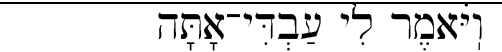 & $3 a$ \\
\hline & & & $\mathrm{b}$ & 3 & 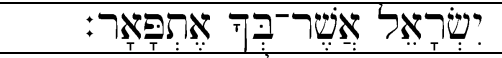 & b \\
\hline & $\mathrm{D}$ & 6 & $\mathrm{a}$ & 4 & 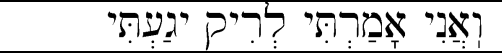 & $4 \mathrm{a}$ \\
\hline & & & $\mathrm{b}$ & 4 & 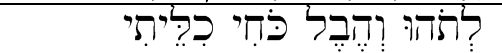 & $\mathrm{b}$ \\
\hline & & 7 & a & 3 & 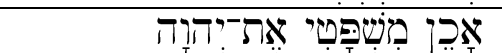 & $\mathrm{c}$ \\
\hline & & & $\mathrm{b}$ & 2 & 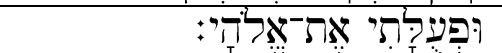 & $\mathrm{d}$ \\
\hline \multirow[t]{11}{*}{ III } & $\mathrm{E}$ & 8 & $\mathrm{a}$ & 3 & 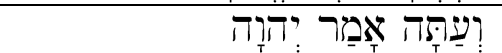 & $5 \mathrm{a}$ \\
\hline & & & $\mathrm{b}$ & 4 & 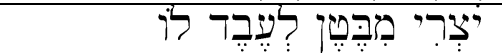 & $\mathrm{b}$ \\
\hline & & 9 & $\mathrm{a}$ & 3 & 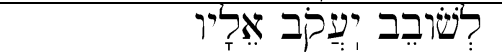 & $\mathrm{c}$ \\
\hline & & & $\mathrm{b}$ & 3 & 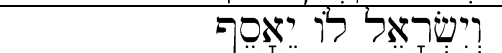 & $\mathrm{d}$ \\
\hline & & 10 & $\mathrm{a}$ & 3 & 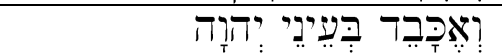 & $\mathrm{e}$ \\
\hline & & & $\mathrm{b}$ & 3 & 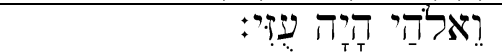 & $\mathrm{f}$ \\
\hline & & 11 & $\mathrm{a}$ & 5 & 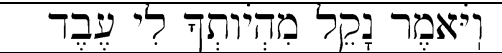 & $6 \mathrm{a}$ \\
\hline & & & $\mathrm{b}$ & 3 & 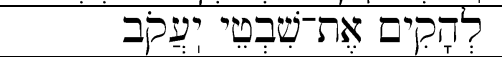 & $\mathrm{b}$ \\
\hline & & & $\mathrm{c}$ & 3 & 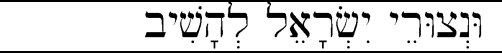 & $\mathrm{c}$ \\
\hline & & 12 & $\mathrm{a}$ & 3 & 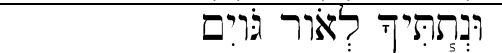 & $\mathrm{d}$ \\
\hline & & & $\mathrm{b}$ & 4 & 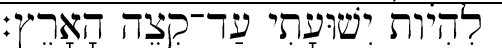 & $\mathrm{e}$ \\
\hline
\end{tabular}

Uit die stigometriese analise van Jesaja 49:1-6 kan die volgende opmerkings gemaak word. Jesaja 49:1-6 is 'n gedig wat uit twaalf stiges (versreëls) opgebou is. Elf van die stiges is distiges (versreëls met twee versvoete). Slegs stige 11 is 'n tristige ('n versreël met drie versvoete).

Op grond van sintaktiese, retoriese en semantiese kriteria kan hierdie twaalf stiges soos volg in ses strofes saamgegroepeer word: 
- $\quad$ Stige 1 (met sy twee opdragte) vorm op sy eie strofe A.

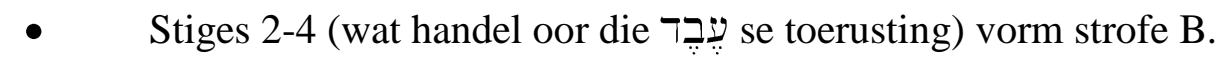

- $\quad$ Stige 5 (wat sê waarvoor Jahwe sy بֶּבֶ geroep het) vorm strofe C.

- $\quad$ Stiges 6-7 (wat die gevolg van die עיקבר se werk beskryf) vorm strofe D.

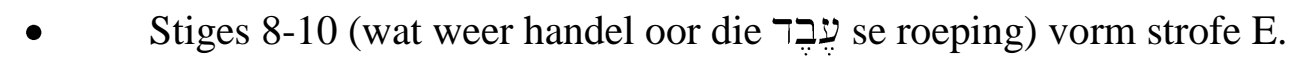

- $\quad$ Stiges 11 en 12 (wat handel oor die uitbreiding van sy roeping) vorm strofe F.

Op grond van dieselfde kriteria kan die ses strofes van 49:1-6 soos volg in stansas saamgegroepeer word: Strofe A is, as inleiding, stansa I. Strofe B (die עִ קברד se toerusting), strofe C (God se doel met die roeping), en strofe D (die gevolge van die עֶרֶ se werk) vorm saam stansa II. Strofe E (wat weer handel oor die עֶרֶ se oorspronklike roeping) en strofe F (wat sê hoe sy roeping uitgebrei word) vorm saam stansa III (vgl ook Steck 1992:8-9).

\subsection{Poëtiese analise}

Die tweede faset van die stilistiese analise van Jesaja 49:1-6 is 'n poëtiese analise wat uit twee afdelings bestaan:

\subsubsection{Identifisering van poëtiese strategieë}

Om uitsprake te beklemtoon, of sekere betekenisnuanses te verkry, gebruik die digter alliterasie (in elke versvoet); assonansie (in elke versvoet); parallellismes (tussen versvoete $1 \mathrm{a}$ en $1 \mathrm{~b}, 2 \mathrm{a}$ en $2 \mathrm{~b}, 6 \mathrm{a}$ en $6 \mathrm{~b}, 7 \mathrm{a}$ en $7 \mathrm{~b}, 8 \mathrm{a}$ en $8 \mathrm{~b}$, en 10a en 10b); chiasmes (tussen versvoete $3 \mathrm{a}$ en $3 \mathrm{~b}, 4 \mathrm{a}$ en $4 \mathrm{~b}, 9 \mathrm{a}$ en $9 \mathrm{~b}$, en $11 \mathrm{~b}$ en 11c); sinekdogee (in versreël 2); metafore (in versreëls 3, 4 en 12); vergelykings (in versreëls 3 en 12); personifikasie (in versreël 1); delesie (in versreëls 2 en 5); rym (in versreëls 4 en 6); herhaling (in versreël 4); hiperbool (in versreël 12); merisme (in versreël 9); inversie (in versreëls 2 en 6); en antiteses (tussen versreëls 5 en 6). 


\subsubsection{Funksies van die poëtiese strategieë}

Die digter gebruik hierdie poëtiese strategieë soos volg:

Stige 1 - Deur middel van assonansie, alliterasie, parallellisme en semanties verwante begrippe bewerk die digter herhaling op die klankvlak, die retoriese vlak sowel as die semantiese vlak. Die effek hiervan is 'n sterk beklemtoning van die erns sowel as die omvang van die inleidende opdragte: Alle mense moet baie goed luister na wat Jahwe deur sy dienaar sê. Met die personifikasie in hierdie stige word verder beklemtoon dat ook dié wat veraf woon, na Jahwe se עִבְב moet luister.

Stige 2 - In stige 2 maak die digter van sewe poëtiese strategieë gebruik: Assonansie, alliterasie, parallellisme en semanties verwante begrippe. Hy gebruik hierdie tegnieke om te beklemtoon dat hy reeds voor sy geboorte tot diens geroep is. Inversie en delesie word gebruik om te onderstreep dat niemand minder nie as Jahwe self op hom beslag gelê het; en sinekdogee word gebruik om te beklemtoon dat God sy hele wese opgeëis het.

Stiges 3 en 4 - In stiges 3 en 4 gebruik die digter naas assonansie, alliterasie, chiasmes en semanties verwante begrippe ook herhaling en rym om twee sake te beklemtoon, naamlik die deeglikheid waarmee Jahwe sy עֶבֶד toerus; en die beskerming wat Jahwe vir hom waarborg. Hierbenewens maak die digter ook gebruik van twee metafore om vooropstelling te bewerk: Deur die עֶקֶ se mond 'n "skerp swaard" te noem, lê hy klem op die effektiwiteit en die deurdringingsvermoë van die boodskap wat die שֶׁר moet oordra. En deur die עֶבֶ self te beskryf as 'n "skerp pyl”, sinspeel hy op die boogskutter (naamlik Jahwe) se vermoë om sy "pyl" (die (עֶברד) doeltreffend te gebruik: As Jahwe hom uitstuur, móét sy sending slaag (vgl Koole 1998:2).

Stige 5 - Deur delesie kan אזָז wat aan die einde van versvoet 5a voorkom, ook aan die begin van versvoet $5 \mathrm{~b}$ veronderstel word. Hierdie strategie versterk die moontlikheid dat die עֶבֶב wat hier "Israel" genoem word, eerder 'n enkeling as 'n groep mense is.

Stige 6 - Versvoete $6 \mathrm{a}$ en $6 \mathrm{~b}$ word deur middel van parallelle opbou en eindrym nóú saamgebind. Die effek hiervan is 'n beklemtoning van die feit dat die עֶֶֶ baie teenstand ervaar het: Dit het soms vir hom gevoel asof hy tevergeefs swoeg. 
Stige 7 - In hierdie stige gebruik die digter antitese en parallellisme om te beklemtoon dat geen weerstand die עִקֶר sal stuit nie: Omdat God oor hom beskik, sál hy slaag.

Stiges 8 en 9 - Die groot hoeveelheid herhalings wat in hierdie stiges voorkom (op konsonantvlak, vokaalvlak, morfologiese vlak, retoriese vlak, en semantiese vlak) verskaf deurslaggewende bevestiging van die beskouing dat die woord לא (nie) in stige 9 gelees moet word as לו (tot Hom). Die parallelisme en die merisme wat op dié wyse tot stand kom, beklemtoon die feit dat Jahwe sy verstrooide volk weer na Hom toe wil laat terugkeer.

Stige 10 - Deur middel van assonansie, alliterasie, parallellisme en semanties verwante begrippe beklemtoon die עֶּר dat dit vir hom 'n groot eer is dat Jahwe hom in sy diens laat staan.

Stige 11 - In stige 11 gebruik die digter saam met assonansie, alliterasie, chiasmes en semanties verwante begrippe ook 'n teenstelling (ingelei met "Dit is te gering") om te beklemtoon dat die עִ עִרד se taak uitgebrei word: Waar hy tot nou toe net moes omsien na Israel alleen, sal hy in die toekoms Jahwe se redding ook aan ander volke moet verkondig.

Stige 12 - In stige 12 gebruik die digter assonansie, alliterasie en semanties verwante begrippe om te beklemtoon dat álle nasies nou deel gaan kry aan Jahwe se gawes - nie meer Israel alleen nie. Met die metafoor in stige 12 ("lig vir die nasies") beklemtoon hy dat Jahwe veel meer is as net 'n plaaslike God wat aan een volk behoort. Hy is God oor álle volke. Met die hiperbool in stige 12 (“die uithoeke van die aarde") lê die digter klem op die feit dat Jahwe álle mense op aarde wil red. Boonop sluit stige 12 ("eindes van die aarde") aan by stige 1 ("volke daar ver"). Deur hierdie inclusio word die gedig afgerond tot 'n sinvolle eenheid (vgl Steck 1992:9).

\section{DIACHRONIESE ANALISE}

In hierdie faset van die eksegese word erns gemaak met die feit dat Jesaja 49:1-6 ook binne ekstratekstuele relasies staan. Die stappe waardeur hierdie relasies bestudeer word, is Gattung-kritiek, motief- en tradisiekritiek. 


\subsection{Gattung-kritiek}

\subsubsection{Gattung}

Jesaja 49:1-6 word op verskillende maniere getipeer. Westermann (1966:208) sien in die betrokke gedeelte "traces of the call of a prophet". Schneider (1993:161) beskou die gedeelte as een van die "Gerichtsreden Gottes an die Völker". Beuken (1983:11, 13) noem die eerste deel van die perikoop (vers 1-3) 'n roepingsverhaal, en die tweede deel (vers 4-6) 'n godspraak. Steck (1992:7) wys op die ooreenkomste tussen Jesaja 49:1-6 en Psalm 2:7-9, wys op die "koningsterminologie" en beskou die teks as die beskrywing van 'n "Amptseinsetzung durch Jahwe". Koole (1998:5) wys daarop dat beide die profetiese en die koninklike aspekte wat in die perikoop aanwesig is, in die bepaling van die Gattung in gedagte gehou moet word.

\subsubsection{Agtergrond}

Die agtergrond waarteen Jesaja 49:1-6 verstaan moet word, is die verbondsverhouding tussen Jahwe en sy uitverkore volk teen die einde van die Babiloniese ballingskap. Hierdie verhouding is vroeër as gevolg van die volk se ontrou verbreek. Nou het die verhouding egter as gevolg van Jahwe se liefdevolle tugtiging herstel tot 'n funksionele verhouding. Die עִ עִברד se roepingsgeskiedenis het sy plek en funksie binne hierdie konteks.

\subsubsection{Funksie}

Die funksie van Jesaja 49:1-6 teen die agtergrond van die Babiloniese ballingskap is om die volk in ballingskap van die volgende vier waarhede te verseker: Jahwe het sy volk nie finaal verwerp nie. Hy wil sy volk weer laat terugkom na Hom toe. Om dit te doen, stel

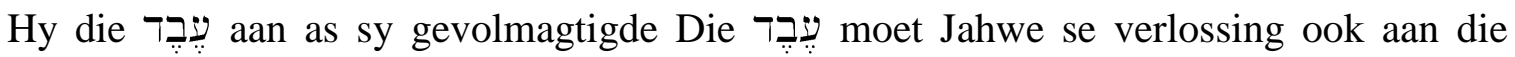
nasies buite Israel verkondig.

\subsection{Motief- en tradisiekritiek}

\subsubsection{Motiefkritiek}

Die volgende geykte motiewe kom voor in Jesaja 49:1-6: Jahwe is die alwetende God (vers 1), Jahwe is die almagtige God (verse 1, 2, 3, en 6), Jahwe is die genadige God wat vir Hom 'n volk uitkies (verse 1, 3, 5, en 6). 


\subsubsection{Geskiedenistradisies}

Die volgende tradisies oor die geskiedenis van Israel kom in die gedig voor: Die skeppingstradisie (verse 1 en 5), en die aartsvadertradisie (verse 5 en 6).

\subsubsection{Funksies}

Die funksies van die motiewe en tradisies in 49:1-6 kan soos volg beskryf word. Die doel daarvan is eerstens een van vertroosting: Dat Israel in ballingskap weggevoer is, beteken nie dat Jahwe sy volk finaal verwerp het nie. Hy wat hulle al van die aartsvaders se tyd af uitverkies het, wil hulle nog steeds na Hom toe laat terugkeer. Voorts is die doel daarvan geloofsversterking. Dat die Babiloniërs Israel verslaan het, beteken nie dat Jahwe nou deur Babilon se gode onttroon is nie. Hy bly nog steeds die enigste God, wat alles weet, en wat tot alles in staat is. Dan dien hierdie gedeelte verder ook tot bemoediging. Omdat Jahwe die Skepper is, kan Hy uit die chaos van die ballingskap 'n nuwe bedeling skep wat beter sal wees as die vorige.

\subsection{Teologiese kritiek}

Op grond van die resultate van die eksegetiese stappe tot dusver kan daar nou afleidings gemaak word oor die teologiese boodskap van Jesaja 49:1-6. By monde van die עִבְד word in hierdie eenheid daarop klem gelê dat Jahwe, die Skepper, almagtig en alwetend is. Hy staan in ' $n$ bepaalde verhouding tot die עִּק: Jahwe het hom self uitgekies en hom self toegerus vir sy taak. Toe die עִ שֶרֶ nie die resultate lewer wat daar van hom verwag is nie, het Jahwe hom nie verwerp nie, maar hom bly gebruik. Jahwe het trouens sy taak uitgebrei. Jahwe se verhouding met sy volk kry ook besondere aandag in die eenheid. Jahwe het nie sy volk verwerp nie, selfs nie in die ballingskap nie. In hulle nood het hy hulle nie vergeet nie, maar hulle gehelp. Sy bedoeling was dat hulle na Hom toe moes terugkeer. In sy verhouding tot die nasies is Jahwe nie net God oor alle nasies nie; Hy wil hulle ook verlos, al is hulle nie deel van sy volk nie. ${ }^{5}$

5 Hierdie uiteensetting bevestig die tese van Beuken (1978:23) dat daar 'n dramatiese voortgang in Deutero-Jesaja aanwesig is. In Jesaja 40-48 gebeur die volgende: "Het woord van JHWH komt tot de ballingen, overwint hun twijfels aangaande Israëls rechtzaak en zijn weg, brengt Babel en haar goden ten val en gebiedt tenslotte uit te trekken." In 49:1-6 "is het gehoorzame deel van Jakob aldus het Israël geworden, waarin JHWH zich verheerlijkt (49:3). Dit is de knecht die Hij zich van oudsher verkoren heeft. Deze knecht heeft in zijn vergeefse arbeid ten bate van alle stammen van Jakob zijn vertrouwen op JHWH niet verloren. Door uit te trekken richt hij zich tot de volken, volbrengt hij aan hen zijn nieuwe taak hen licht te bezorgen en gaat Gods heil reiken tot aan het einde der aarde" (1978:39). 


\section{RESEPSIE-KRITIESE ANALISE}

Tydens die laaste fase van hierdie eksegese word rekening gehou met die feit dat 'n teks eers werklik betekenis kry wanneer die eksegeet vanuit sy eie teologiese voorveronderstellings daaraan betekenis "toeken".

\subsection{Vorige resepsies van die teks}

Jesaja 49:1-6 is deur die eeue vanuit verskillende voorvonderstellinge geïnterpreteer: Die skrywer van die Johannes-evangelie lê met sy beskrywing van Kajafas se woorde oor Christus 'n verband tussen die kneg (עֶבר) se roeping om 'n "lig vir die nasies" te wees (Jes 49:6), en Christus se taak om "die verstrooide kinders van God tot 'n eenheid saam te voeg" (Joh 11:52). Paulus sê in Handelinge 13 dat hy en Barnabas van God opdrag ontvang het om die evangelie aan die heidene te verkondig. As bewys hiervan haal hy aan uit Jesaja 49:6. Daarmee maak hy God se opdrag aan die kneg om 'n "lig vir die nasies" te wees op homself en Barnabas van toepassing.

Calvyn (1948:11) sien in die kneg van Jesaja 49:1-6 'n profetiese heenwysing na Christus. Hy gaan selfs verder deur die vermelding van Israel in Jesaja 49:3 te beskou as 'n verwysing na die kerk van Christus.

Duhm (1892:284) sien in die עֶבר 'n onbekende leraar wat geweldadig gesterf het. Mowinckel (1959:188) sê aanvanklik dat die שֶקר Deutero-Jesaja self was; later sê hy dat sy identiteit onbelangrik is. Volz (1932:37) beskou die עֶבק as Deutero-Jesaja self, en Elliger (1933:11) meen dat dit Trito-Jesaja is. Rowley (1965:13), Robinson (1936:49) en Kaiser (1959:57) beskryf die עִ עִברד as 'n "kollektiewe persoonlikheid". Melugin (1976:146) meen dat die naam "Israel" in Jesaja 49:3 bedoel is as 'n gerusstelling aan die ballinge dat God nog steeds aan Israel bly vashou het as sy uitverkore volk. Haller (1923:266) en McKenzie (1968:106) identifiseer die עֶבֶ as die Persiese koning Kores, en Torrey (1926:136) sê die עִברד is Abraham of Israel wat gepersonifieer word.

Uit hierdie voorbeelde blyk twee sake duidelik: Elke eksegeet kom met sy eie vooronderstellings na die teks, en daar word soms aan die teks betekenisse toegeken wat nie in die teks aanwesig is nie. 


\section{2 'n Eie toekenning van betekenis aan Jesaja 49:1-6}

\subsubsection{Teksfunksie van Jesaja 49:1-6}

Dit is belangrik dat die toekenning van betekenis nie berus op blote willekeur nie. Daarom behoort die volgende sake in verband met die teksfunksie van Jesaja 49:1-6 baie deeglik in ag geneem te word. Hoewel daar onsekerheid bestaan oor die identiteit van die עִברד (of dit 'n enkeling, 'n korporatiewe persoonlikheid of 'n profetiese heenwysing is), bestaan daar geen onsekerheid oor sy gesag nie. Hy is deur Jahwe gestuur. Daarom dra sy oproepe en sy boodskap gesag.

Hoewel die עֶבֶד in Jesaja 49:1-6 uiteenlopende dinge oor 'n verskeidenheid mense sê, is die primêre doel van die perikoop om inligting oor God te gee - om te verkondig hoe Hy onder sekere omstandighede met sekere mense gehandel het. Hoewel die oorspronklike agtergrond van Jesaja 49:1-6 die verbondsverhouding tussen Jahwe en sy volk was teen die einde van die Babiloniese ballingskap, dra die perikoop 'n teologiese boodskap wat deur eeue heen opnuut geldig is vir elke gelowige van elke plek en tyd.

\subsubsection{Die teologiese boodskap van Jesaja 49:1-6}

Vir die verbondsvolk wat tydens die ballingskap begin moed verloor het, het Jesaja 49:15 die versekering gegee: Daar is hoop, want God wat julle eenmaal laat wegvoer het, wil julle weer na Hom toe laat terugkeer. Vir mense wat buite die verbondsverhouding van God moes leef, bring Jesaja 49:6 die boodskap: Daar is vir julle ook plek by God. Hy wil júlle ook by Hom versamel. Vir mense wat tydens Jesus van Nasaret se lewe nie mooi kon begryp waarvoor Hy geleef (en later gesterf) het nie, het Jesaja 49:1-6 die moontlikheid gebied om in te sien dat die toegang tot God vir hulle oop is.

Vir die volgelinge van Christus wat ná sy hemelvaart onseker en selfs weerloos gevoel het, het Jesaja 49:1-6 'n bron van krag en vertroosting geword. So is gelowiges soos Paulus en Barnabas geïnspireer om hulle eie werk onder die heidene (Hand 13:17) te vereenselwig met die kneg se roeping ten opsigte van die nasies.

Gedurende die 18de eeu het gedeeltes soos Jesaja 49:1-6 baie daartoe bygedra dat die kerk sy sendingopdrag herontdek en begin erns maak het met die verkondiging van die evangelie aan die heidennasies van die wêreld. 
Vir Christene wat in die moderne tyd te midde van misdaad, geweld, moord, armoede en sedelike verval moet leef, en wat vrae vra oor die wyse waarop God beheer uitoefen in die wêreld, sny die boodskap van Jesaja 49:1-6 na twee kante: Aan die een kant is dit 'n boodskap van hoop. Die kneg verseker hierdie gelowiges dat God hulle nie vergeet het of die band met hulle deurgesny het nie. Hy is te midde van die chaos in die wêreld nog steeds met sy gelowiges op pad na 'n ryk waar daar orde en vrede sal wees. Aan die ander kant lê Jesaja 49:1-6 die verantwoordelikheid op hulle om die boodskap van hoop ook te bring aan diegene wat buite die gemeenskap met God lewe.

\section{Literatuurverwysings}

Beuken, W A M 1978. De vergeefse moeite van de knecht: Gedachten over de plaats van Jesaja 49:1-6 in de context, in De knecht: Studies rondom Deutero-Jesaja door collega's en oud-leerlingen aangeboden aan Prof. Dr. J. L. Koole. Kampen: J H Kok.

Beuken, W A M 1983. Jesaja Deel II B. Nijkerk: Callenbach. (POT).

Calvyn, J 1948. Commentary on the prophet Isaiah, uit Latyn vertaal deur W Pringle. Grand Rapids: Eerdmans. (Calvin's Commentaries).

Duhm, B 1892. Das Buch Jesaja. Göttingen: Vandanhoeck \& Ruprecht.

Elliger, K 1933. Deuterojesaja in seinem Verhältnis zu Tritojesaja. BWANT 4, 7-21.

Haller, E 1923. Die Kyros-lieder Deuterojesajas. FRLANT 27, 261-277.

Kaiser, O 1959. Der königliche Knecht. Vandenhoeck \& Ruprecht.

Koole, J L 1998. Isaiah, Part 3, Volume 2: Isaiah 49-55. Leuven: Peeters. (HCOT.)

McKenzie, J L 1968. Second Isaiah. New York: Doubleday. (Anchor Bible).

Melugin, R F 1976. The formation of Isaiah 40-55. BZAW 78, 141-159.

Mowinckel, S O P 1959. He that cometh. Oxford: Blackwell.

North, C R 1948. The suffering servant in Deutero-Isaiah: An hiostorical and critical study. London: Oxford University Press.

Robinson, H W 1936. The Hebrew Conception of Corporate Personality. BZAW 66, 4764.

Rowley, H H 1965. The servant of the Lord. Oxford: Blackwell. 
Spykerboer, H C 1976. The stucrure and composition of Deutero-Isaiah with special reference to the polemics against idolatry. Meppel: Krips Repro.

Schneider, D 1993. Der Prophet Jesaja, 2. Teil. Zurich: R Brockhaus. (Wuppertaler Studienbibel).

Sellin, E 1922. Mose und seine Bedeutung für die israelitisch-jüdische Religionsgeschichte. Leipzig: Quelle und Meyer.

Sellin, E 1930. Tritojesaja, Deuterojesaja und das Gottesknechtsproblem. NKZ 41, 77393.

Steck, O-H 1992. Gottesknecht und Zion: Gesammelte Aufsätze zu Deuterojesaja. Tübingen: J C B Mohr (Paul Siebeck). (Forschungen zum Alten Testament 4.)

Torrey, C C 1928. The second Isaiah: A new interpretation. New York: Scribner.

Volz, P 1932. Jesaja, II. Leipzig: Deichert. (KZAT 9,2).

Westermann, C 1966. Isaiah 40-66. London: SCM. (OTL). 